\title{
The population density of Lymnaea columella (Say, 1817) (Mollusca, Lymnaeidae) an intermediate host of Fasciola hepatica (Linnaeus, 1758), in the Caparaó microregion, ES, Brazil
}

\author{
S. C. G. D'Almeida ${ }^{a *}$, D. F. Freitas ${ }^{b}$, M. B. Carneiro , $^{\text {, P. F. Camargo }}$, \\ J. C. Azevedo and I. V.F. Martins ${ }^{d}$ \\ anidade de Investigação em Parasitologia Médica, Instituto de Higiene e Medicina Tropical, \\ Universidade Nova de Lisboa, Rua da Junqueira 100, 1300114, Lisboa, Portugal \\ ${ }^{b}$ Centro de Biociências e Biotecnologia, Universidade Estadual do Norte Fluminense Darcy Ribeiro, \\ Av. Alberto Lamego, 2000, CEP 28013-600, Campos dos Goytacazes, RJ, Brazil \\ 'Departamento de Medicina Veterinária, Escola Superior São Francisco de Assis, Rua Bernardino Monteiro, 700, \\ CEP 29650-000, Santa Teresa, ES, Brazil \\ dDepartamento de Medicina Veterinária, Laboratório de Parasitologia, Universidade Federal do Espírito Santo, \\ Alto Universitário, s/n, CEP 29500-000, Alegre, ES, Brazil \\ *e-mail: samiradalmeida@gmail.com
}

Received: August 4, 2014 - Accepted: June 23, 2015 - Distributed: May 31, 2016

(With 2 figures)

\begin{abstract}
The aim of this study was to monitor the population density of Lymnaea columella, an intermediate host of Fasciola hepatica, in various aquatic habitats and in drinking water in the area of the Instituto Federal de Educação, Ciência e Tecnologia do Espírito Santo, on Caparaó Microregion, municipality of Alegre, state of Espírito Santo, Brazil. Monthly samplings were performed at certain points between drainage areas and drinking water in cattle and goat production systems during the years 2010 to 2013. The mean temperature, precipitation and the frequency of samples of L. columella were analysed graphically according the monthly average during the study period. A total of 2,038 molluscs were collected, 1558 of which were L. columella, that predominated in all sampled points. The highest average of specimens observed for L. columella was in the years 2010 and 2013 (51.0), and occurred decreased in 2011 (19.8). The temperature and precipitation averaged is $23.7{ }^{\circ} \mathrm{C}$ and $141 \mathrm{~mm} /$ year, respectively. Rainfall peak occurred in March $(2011,2013)$ and November (2012), during these periods the population of $L$. columella growth. There was no significant difference in the relationship between the specimens observed with seasons (dry-wet), thus the population of L. columella remained stable and can be found throughout the year.
\end{abstract}

Keywords: molluscs, population, rainfall, temperature.

\section{Densidade populacional de Lymnaea columella (Say, 1817) (Mollusca, Lymnaeidae) hospedeiro intermediário de Fasciola hepatica (Linnaeus, 1758) na Microrregião do Caparaó, ES, Brasil}

\section{Resumo}

O objetivo deste estudo foi acompanhar a variação da densidade populacional de Lymnaea columella, hospedeiro intermediário de Fasciola hepatica, em diferentes tipos de coleções hídricas e bebedouros na área do Instituto Federal de Educação, Ciência e Tecnologia do Espírito Santo, na microrregião do Caparaó, município de Alegre, estado do Espírito Santo, Brasil. Foram realizadas coletas mensais em pontos determinados entre áreas de drenagem e bebedouros de animais nos setores de bovinocultura e caprinocultura durante os anos de 2010 a 2013 . As médias de temperatura, precipitação e a frequência de exemplares de L. columella foram analisadas graficamente de acordo com a média mensal ao longo do período avaliado. Foram coletados 2.038 moluscos, sendo 1558 de L. columella, espécie predominante em todos os pontos amostrados. A maior média de espécimes observadas para L. columella foi nos anos de 2010 e 2013 (51,0), ocorrendo um decréscimo em 2011 (19,8). A temperatura apresentou média de $23,7^{\circ} \mathrm{C}$ e precipitação de $141 \mathrm{~mm} /$ ano. Picos de precipitação ocorreram em Março (2011, 2013) e Novembro (2012), nestes períodos foi observado aumento populacional de L. columella. Não houve diferença significativa na relação entre as espécimes observadas com as estações do ano (seca-chuvosa), dessa forma, a população de L. columella se mostrou estável, podendo ser encontrada durante todo ano.

Palavras-chave: moluscos, população, precipitação, temperatura. 


\section{Introduction}

Molluscs of the Lymnaeidae family have a cosmopolitan distribution, and in Brazil the Lymnaea genus is represented by three species: L. viatrix (d'Orbigny, 1835), L. cubensis (Pfeiffer, 1839) and L. columella (Say, 1817), all recognized as intermediate hosts of the trematode Fasciola hepatica (Linnaeus, 1758), etiologic agent of bovine fasciolosis (Maure et al., 1998).

Lymnaea columella has a wide geographical distribution, being found in state of Espírito Santo (Medeiros et al., 2014). The structure and abundance of its populations are directly related to the intrinsic interactions of the species and extrinsic properties imposed by the local habitat. In addition, factors as temperature, rainfall and human actions are regarded as especially important in the structural process of establishment and population survival (Ollerenshaw, 1971; Torgerson and Claxton, 1999).

Populations of this mollusc are subject to many ecological constraints imposed by temporal fluctuations in their environment (Gérard, 2001). Explosive growth because of high reproductive rates under favorable conditions alternate with drastic declines under unfavorable periods in for its development (Malone et al., 1984). Accordingly, small populations can quickly recover in number, since individuals are also able to self-fertilization (Dillon, 2004).

Similarly, the epidemiology of fasciolosis is linked to environmental and climatic factors, and its occurrence is usually associated with areas of high slope and precipitation, which contributes fairly to the establishment of wetlands, important niches for the maintenance of $L$. columella (Dutra et al., 2010). In this context, the state of Espírito Santo becomes a potential breeding site, due to the warm and humid climate and local topography to the development of the parasite and its host (Bernardo et al., 2011). Martins et al. (2012) observed the existence of risk areas for fasciolosis in the southern region of this state and Freitas et al. (2014) reported prevalence rates of up to $28.41 \%$ for the disease. These data reflect the importance of the state of Espírito Santo as being a reservoir area for the disease and investigations on factors that determine mollusc species richness and distribution in wetland systems are scarce in the Neotropical region (Maltchik et al., 2010).

Considering that knowledge of the time of occurrence of mollusc is most important for the establishment of control programs for fasciolosis, and the population studies of the intermediate hosts contribute to the knowledge of the ecology of these, the aim of this study was to monitor the population density of $L$. columella in various aquatic habitats and in drinking waters from production systems at the Instituto Federal de Educação, Ciência e Tecnologia do Espírito Santo on Caparaó Microregion, state of Espírito Santo, during the years 2010 to 2013 .

\section{Material and Methods}

\subsection{Location of the experiment}

The experiment was conducted from November 2010 to June 2013. Monthly samplings were performed at five selected points representing drainage areas and drinking water in cattle and goat production systems at the Instituto Federal de Educação, Ciência e Tecnologia do Espírito Santo (IFES), located in the city of Alegre, state of Espírito Santo, in the Caparaó microregion. The collect points were delimited in an area of $1 \mathrm{~m}^{2}$, perpendicular at your source. Point 1 was a drinking water reservoir for calves in a cattle production system (S $20^{\circ} 45^{\prime} 880^{\prime}$, W $41^{\circ} 27^{\prime} 319^{\prime}$ '). Point 2 was a wetland close to the reservoir for a drinking water for calves in a cattle production system (S 2045'879', W 41 $\left.27^{\circ} 270^{\prime \prime}\right)$. Point 3 was a drinking water reservoir for a goat production system (S 2045'692”, W 41 $277^{\prime} 556^{\prime \prime}$ ). Point 4 and 5 were a drinking water reservoir for goats (S 2045'691', W 41'27'544' and S 2045'682', W 4127'529').

\subsection{Collection and analysis of molluscs}

Molluses in the margins of drinking water reservoir were collected, submersed or not, and in around vegetation. Also collected within the flooded regions, adhering to aquatic and terrestrial plants that were present. Vegetation samples were collected from the area to determine the presence of mollusc eggs. All procedures were performed manually with specific equipment such as sieves, nettings and filters. After collection, the molluscs were sent to the parasitology laboratory of the Hospital Veterinário da Universidade Federal do Espírito Santo (HOVET-UFES), where they were separated according to points, counted and identified according to Paraense (1975, 1983, 1986). Samples of L. columella were directly exposed to artificial light for four hours and then analysed to determine the presence of larval form of $F$. hepatica. This procedure was performed according to the Manual of Surveillance and Control of Molluscs of Epidemiological Importance (Brasil, 2008).

\subsection{Meteorological data collection}

Meteorological data were provided by the Instituto Capixaba de Pesquisa, Assistência Técnica e Extensão Rural (INCAPER). The data were analysed and correlated with the presence of molluscs over the study period.

\subsection{Statistical analysis}

Descriptive tabular statistics were calculated to report the frequency of molluscs collected. Monthly variations in temperature and precipitation relative to the frequency of Lymnaea columella were graphically analysed. Monthly averages were calculated over the study period. The seasons were classified according to precipitation levels: dry season (April to September) and rainy season (October to March). The monthly number of mollusc according to season (dry or rainy) was tested for normality and analyzed nonparametrically with a Mann-Whitney test. A significance level of $p \leq 0.05$ was used for all tests. 


\section{Results}

A total of 2038 molluscs were collected. Of these 1558 (76.45\%) belonged to the genus Lymnaea (d'Orbigny, 1835), 240 (11.78\%) to the genus Physa (Draparnaud, 1801) and $240(11.78 \%)$ to the genus Biomphalaria (Preston, 1910). Points 1 and 5 presented higher average number

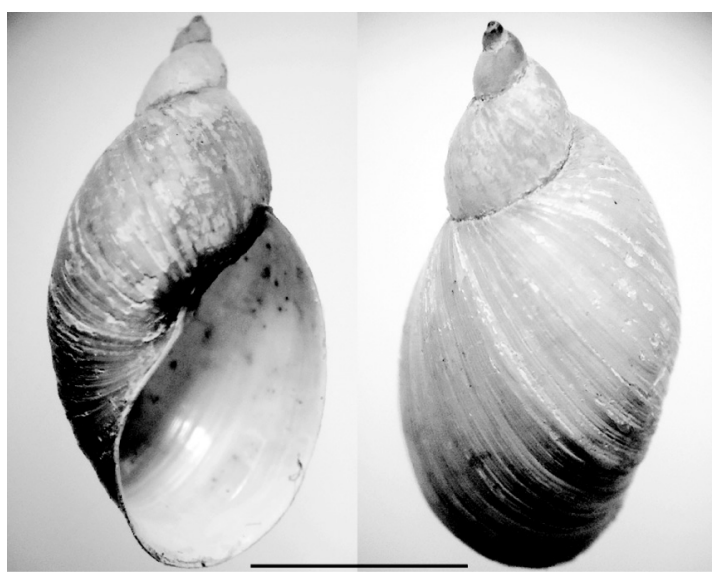

Figure 1. Lymnaea columella (Say, 1817): photograph of a specimem collected in wetlands from Instituto Federal de Educação, Ciência e Tecnologia do Espírito Santo (IFES), in the Caparaó microregion, state of Espírito Santo, Brazil. Scale $=5 \mathrm{~mm}$. Credit of photos: Samira D'Almeida. of molluscs collected per year, with predominance of Lymnaea columella (Say, 1817) (Figure 1). Points 3 and 4 showed higher occurrence of Biomphalaria sp. and point 2 presented higher occurrence of Physa sp. as shown in Table 1. No L. columella specimens showed evidence of the larval stages of Fasciola hepatica.

The average number of $L$. columella collected decreased in 2011. Although only two months of evaluation were performed in 2010, the average number of this species was higher in this year, as in 2013. During the 32 months of study, the average temperature was $23.7{ }^{\circ} \mathrm{C}$, and the average precipitation was $141 \mathrm{~mm}$. The greatest average numbers of L. columella were found in the months with the greatest precipitation. The monthly distribution of these molluscs and the precipitation and temperature data for 2011, 2012 and 2013 are shown in Figure 2.

In 2011, the average precipitation was $130 \mathrm{~mm}$, and the average temperature was $23^{\circ} \mathrm{C}$. Note the extended period of rainfall during the rainy season and the marked decrease during the dry season. The numbers of $L$. columella only began to increase in September, with a slight decrease in January, February and March. The highest temperatures of the year were observed during these three months, averaging $27.1^{\circ} \mathrm{C}, 27.6{ }^{\circ} \mathrm{C}$ and $25^{\circ} \mathrm{C}$, respectively.

The rainfall in 2012 was less than that in 2011. In 2012, the average precipitation was $84 \mathrm{~mm}$, and the average temperature was $24{ }^{\circ} \mathrm{C}$. Lymnaea columella population showed two peaks in 2012. A total of 120 specimens were collected in January, and a total of 134 were collected in

Table 1. Average number of Lymnaea columella (Say, 1817), Physa sp. and Biomphalaria sp. by sampled points in the years 2010, 2011, 2012 and 2013, collected from Instituto Federal de Educação, Ciência e Tecnologia do Espírito Santo (IFES), in the Caparaó microregion, state of Espírito Santo, Brazil.

\begin{tabular}{ccccc}
\hline \multirow{2}{*}{ Points } & Years & & Molluscs & \\
\cline { 2 - 4 } Point 1 & 2010 & Lymnaea columella & Physa sp. & Biomphalaria sp. \\
& 2011 & 19.5 & - & - \\
& 2012 & 26.8 & 0.17 & 0.14 \\
& 2013 & 6.17 & - & - \\
\hline \multirow{3}{*}{ Point 2 } & 2010 & - & 0.15 & - \\
& 2011 & 2.58 & 2.83 & - \\
& 2012 & 0.08 & - & 0.17 \\
\hline \multirow{2}{*}{ Point 3 } & 2013 & - & - & - \\
& 2010 & 17.5 & 8.5 & 6.5 \\
& 2011 & 0.08 & 0.07 & 0.17 \\
\hline \multirow{2}{*}{ Point 4 } & 2012 & - & - & 0.14 \\
& 2013 & - & - & - \\
\hline & 2010 & 3.5 & - & 6.0 \\
& 2011 & - & - & 7.0 \\
& 2012 & 0.33 & - & 0.17 \\
\hline
\end{tabular}




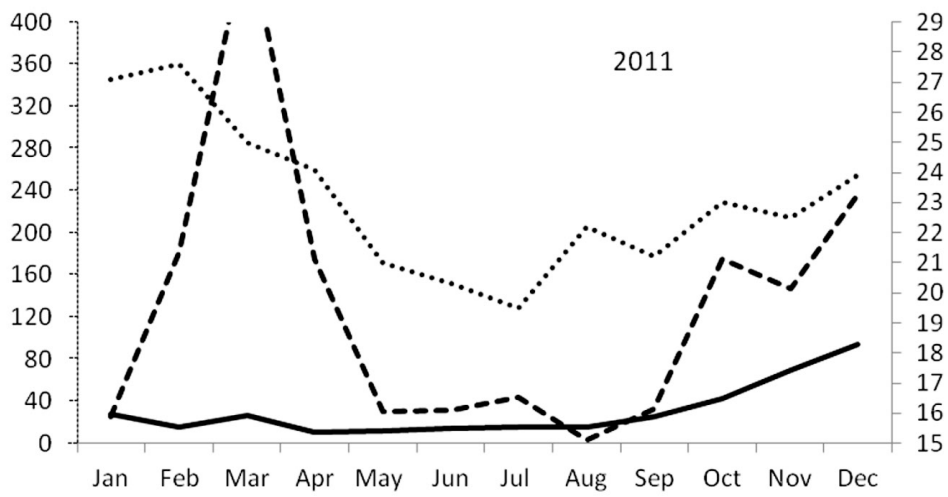

---Precipitation $(\mathrm{mm}) \longrightarrow$ Lymnaea $\quad \cdots . .$. Temperature $\left({ }^{\circ} \mathrm{C}\right)$

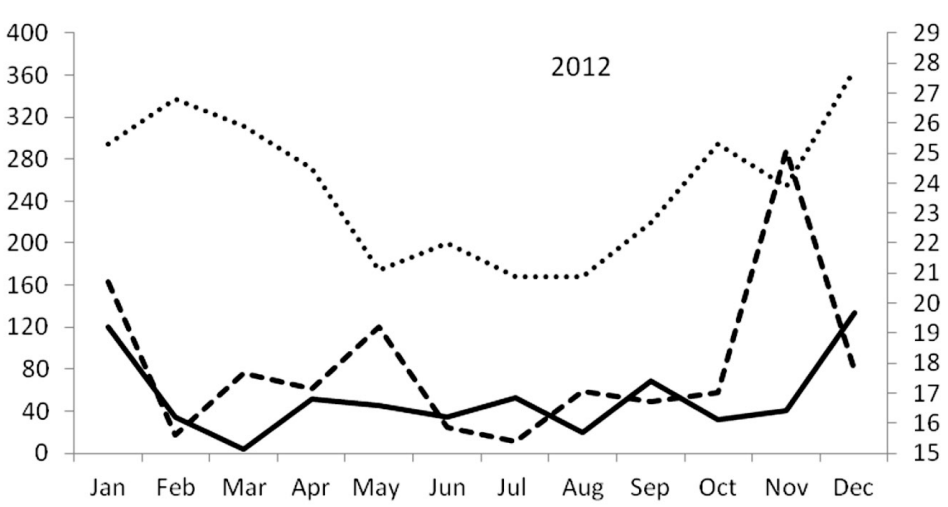

- - - Precipitation $(\mathrm{mm}) \quad$ Lymnaea $\quad \cdots . .$. .. Temperature $\left({ }^{\circ} \mathrm{C}\right)$

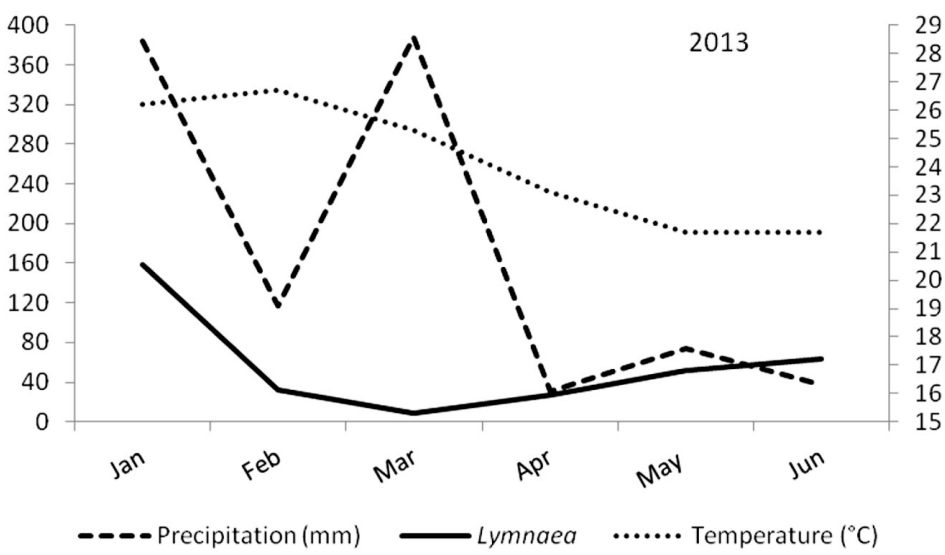

Figure 2. Monthly distribution of Lymnaea columella (Say, 1817), precipitation (mm) and temperature $\left({ }^{\circ} \mathrm{C}\right)$ in the years 2011, 2012 and 2013, from Instituto Federal de Educação, Ciência e Tecnologia do Espírito Santo (IFES), in the Caparaó microregion, state of Espírito Santo, Brazil.

December. These data are consistent with the major peaks of precipitation. In 2013, the averages, computed through June, were $171 \mathrm{~mm}$ precipitation and $24{ }^{\circ} \mathrm{C}$ temperature. Therefore, the seasons were similar in 2013 and 2011, except after March, when the precipitation level corresponded to lower numbers of $L$. columella. The correlation between the monthly number of molluscs and the season was not significant $(\mathrm{p}=0.30)$.

\section{Discussion}

The southern region of the state of Espírito Santo is characterized by the presence of mountainous areas cut by the work of many river valleys that harboured it, thus creating zones of constant floods during the rainy season (Toledo et al., 2009). By to present habits amphibians, molluscs of the genus Lymnaea become extremely dependents on 
environmental constants, since the populations of aquatic molluscs are submitted to severe ecological restraints imposed by temporal fluctuations of their environmental conditions. Their success depends on their physiological capacity to tolerate these fluctuations (Russel-Hunter, 1961). Factors as temperature, precipitation, and anthropogenic influences can also directly affects structure and abundance of these populations (Prepelitchi et al., 2011). Maltchik et al. (2010) observed in southern Brazil that richness and the composition of molluscs were associated with area, altitude, water conductivity and dominant vegetation.

A population decrease was observed at certain sampling points during the study. This decrease resulted from human activity at points 2 and 3. A drainage procedure was performed on the wet land at point 2 . This procedure interfered with the collection of molluscs. These molluscs commonly occur in water tanks, small water reservoirs, irrigation ditches (Coelho and Lima, 2003; Carvalho et al., 2005) and back waters (Serra-Freire, 1995). If these areas are drained, the increased exposure to solar radiation at high temperatures may cause mortality in the mollusc populations. Beginning in January 2011, the reservoir at point 3 was used for other farm activities, resulting in a decrease in the amount of available substrate. As a result, the mollusc populations at points 2 and 3 decreased and eventually disappeared. Similarly, Coelho and Lima (2003) observed $5.2 \%$ to $3.9 \%$ decreases in mollusc populations in an area after removal of aquatic plants and the application of drainage procedures.

Increases in precipitation and temperature levels favour increases in mollusc populations. Müller et al. (1999) have shown that temperatures ranging between $10^{\circ}$ and $25^{\circ} \mathrm{C}$ favour mollusc development. Claxton et al. (1999) have reported similar findings, showing that growth in molluscs is slow at temperatures less than $10^{\circ} \mathrm{C}$, increases rapidly up to $25^{\circ} \mathrm{C}$, and becomes slower if exposure to $25^{\circ} \mathrm{C}$ is prolonged. Consistent with these reports, Martins et al. (2012) have found that one factor that supports the development of intermediate hosts in the southern region of the state of Espírito Santo is an average temperature greater than $20^{\circ} \mathrm{C}$.

However, a slight decrease in growth may result from an increase in temperature that occurs in the dry season, independent of precipitation level. Mas-Coma et al. (2009) have reported that climate changes resulting in higher temperature may negatively affect the development of trematode larvae and the intermediate host of the studied trematodes. In the current study, temperatures of $25^{\circ} \mathrm{C}$ or greater were associated with decreases in the number of molluscs in the study area. In addition, none of the months analysed had average temperatures less than $20^{\circ} \mathrm{C}$. As a result, decrease in the growth rate due to low temperatures was not observed.

Maure et al. (1998) at studying the population dynamic of L. columella grazing in farms positive for bovine fasciolosis, in the municipalities of Piquete and Redenção da Serra of the state of São Paulo, observed that increase in the range of population density fluctuated inversely to temperature and precipitation ranges, concluded that these factors are responsible for establishment or not of these species in the locality studied.

Although the relationship between the number of molluscs and the seasons do not differ significantly, it shows that independent of the season, even presenting the highest average during the rainy season, L. columella occurred during all year. According Maltchik et al. (2010) many bivalve populations are restricted to shallow waters and susceptible to droughts or dry periods, but their study showed that the mollusc richness and composition were similar both in permanent and intermittent wetlands. Thus, the population of this mollusc was stable during the period of study in the sampled points: however, it should be emphasize that for the maintenance of the fasciolosis cycle, the presence of the parasite Fasciola hepatica (Linnaeus, 1758) has to be detected, which was not registered in this study.

Specimens of $L$. columella can spread to other locality due to the influence of precipitation. According Busetti (1982) in certain regions, during the rainy season, population dispersal to surroundings areas can occur. Furthermore, with increase climatic factor to this spread can occur by floods, going to areas closer or more distant areas (Acha and Szyfres, 1986). This dispersion was not registered in this study.

The understanding of population density in L. columella is important to create programmes for the control and treatment of fasciolosis. According to Serra-Freire (1995), large numbers of $F$. hepatica eggs are excreted by the host during the dry season. The eggs hatch at the beginning of the rainy season. Subsequently, large numbers of cercariae are released by molluscs at the primary focus of the disease. Thus, having higher water availability, populations of molluscs may increase and expand foci of dissemination and vulnerability to disease, because the points are studied in the region of high prevalence for fasciolosis, as verified by Freitas et al. (2012). This situation is considered serious, since the beginning of the rainy season cattle leaving a little feeding and face a high infection by intake metacercariae on abundant grassland. Serra-Freire (1990) has stated that even if control is difficult, fascioliasis is a tightly regulated parasitosis with a stable sensitivity to changes in the environment.

Therefore, situations that affect the soil moisture, as precipitation and temperature will change the population density of the host and, as consequence favor their presence or not in environments they are where found. In this context, effective control programs for bovine fasciolosis can be performed in any region, from the moment that the intermediate host population studies are conducted.

\section{Conclusion}

The mollusc L . columella predominated in all sampled points studied and the population remained stable and can be found throughout the year. No L. columella specimens showed evidence of the larval stages of Fasciola hepatica. 


\section{Acknowledgements}

CAPES for the financial support of this project PROCAD 093/2007.

\section{References}

ACHA, P.N. and SZYFRES, B., 1986. Zoonosis y enfermedades transmissibles comunes al hombre y a los animales. Washington, D. C.: Organización Panamericana de La Salud.

BERNARDO, C.C., CARNEIRO, M.B., AVELAR, B.R., DONATELE, D.M., MARTINS, I.V. and PEREIRA, M.J., 2011. Prevalence of liver condemnation due to bovine fasciolosis in Southern Espírito Santo: temporal distribution and economic losses. Revista Brasileira de Parasitologia Veterinária, vol. 20, no. 1, pp. 49-53. http://dx.doi.org/10.1590/S1984-29612011000100010. PMid:21439232.

BRASIL. Ministério da Saúde - MS, 2008. Surveillance and control of molluscs of epidemiological importance: technical guidelines: surveillance Program, and Schistosomiasis Control $(P C E)$. 2nd ed. Brasília: Editora do Ministério da Saúde. 178 p.

BUSETTI, E.T., 1982. Additional information on liver fluke in Curitiba (Paraná, Brazil). Revista do Instituto de Medicina Tropical de Sao Paulo, vol. 24, no. 2, pp. 102-106. PMid:7134738.

CARVALHO, S.O., STEPS, L.K.J., MENDONCA, C.L.F.G., CARDOSO, P.C.M. and BOILER, R.L., 2005. Molluscs of Medical Importance in Brazil. Belo Horizonte: FioCruz/ Centro de Pesquisas René Rachou. 51 p.

CLAXTON, J.R., SUTHERST, J., ORTIZ, P. and CLARKSON, M.J., 1999. The effect of cyclic temperatures on the growth of Fasciola hepatica and Lymnaea viatrix. Veterinary Journal (London, England), vol. 157, no. 2, pp. 166-171. http://dx.doi. org/10.1053/tvjl.1998.0293. PMid:10204412.

COELHO, L.H. and LIMA, W.S., 2003. Population dynamics of Lymnaea columella and its natural infection by Fasciola hepatica in the State of Minas Gerais, Brazil. Journal of Helminthology, vol. 77, no. 1, pp. 7-10. http://dx.doi.org/10.1079/JOH2002138. PMid:12590657.

DILLON, R.T., 2004. The ecology of freshwater molluscs. Cambridge: Cambridge University Press. 499 p.

DUTRA, L.H., MOLENTO, M.B., NAUMANN, C.R.C., BIONDO, A.W., FORTES, F.S., SAVIO, D. and MALONE, J.B., 2010. Mapping risk of bovine fasciolosis in the south of Brazil using Geographic Information Systems. Veterinary Parasitology, vol. 169, no. 1-2, pp. 76-81. http://dx.doi.org/10.1016/j.vetpar.2009.12.015. PMid:20071083.

FREITAS, D.F., MARTINS, I.V., SANTOS, G.M., SANTOS, A.R. and GOMES, D.S., 2014. Bioclimatic distribution and prevalence maps for Fasciola hepatica in Espírito Santo State, Brazil. The Journal of Venomous Animals and Toxins Including Tropical Diseases, vol. 29, no. 32, pp. 1-11. PMid:25101121.

FREITAS, D.F., MARTINS, I.V.F., TULER, V.O., SANTOS, G.M. and SANTOS, A.R., 2012. Vulnerability to the occurrence of Fasciolosis in the Experimental Area of the Federal Institute of Education, Science and Technology of Espírito Santo, IFES, Alegre, ES, Brazil. Arquivos do Instituto Biologico, vol. 79, no. 4, pp. 533-540. http://dx.doi.org/10.1590/S1808-16572012000400010.
GÉRARD, C., 2001. Consequences of a drought on freshwater gastropod and trematode communities. Hydrobiologia, vol. 459, no. 1/3, pp. 9-18. http://dx.doi.org/10.1023/A:1012567102396.

MALONE, J.B., LOYACANO, A.F., HUGH-JONES, M.E. and CORKUM, K.C., 1984. A three-year study on seasonal transmission and control of Fasciola hepatica of cattle in Louisiana. Preventive Veterinary Medicine, vol. 3, no. 2, pp. 131-141. http://dx.doi. org/10.1016/0167-5877(84)90003-5.

MALTCHIK, L.A., STENERT, C.A., KOTZIAN, C.B.B. and PEREIRA, D.C., 2010. Responses of freshwater molluscs to environmental factors in Southern Brazil wetlands. Brazilian Journal of Biology $=$ Revista Brasileira de Biologia, vol. 70, no. 3, pp. 473-482. http://dx.doi.org/10.1590/S1519-69842010005000003. PMid:20737115.

MARTINS, I.V.F., AVELAR, B.R., PEREIRA, M.J.S. and FONSECA, A.H., 2012. Application of a geographical information system approach for risk analysis of fascioliasis in southern Espírito Santo state, Brazil. Geospatial Health, vol. 6, no. 3, pp. 87-93. http://dx.doi.org/10.4081/gh.2012.126. PMid:23032288.

MAS-COMA, S., VALERO, M.A. and BARGUES, M.D., 2009. Climate change effects on trematodiases, with emphasis on zoonotic fascioliasis and schistosomiasis. Veterinary Parasitology, vol. 163, no. 4, pp. 264-280. http://dx.doi.org/10.1016/j.vetpar.2009.03.024. PMid:19375233.

MAURE, E.A.P., BUSTAMANTE, M., SERRA-FREIRE, N.M. and GOMES, D.C., 1998. Population dynamic of Lymnaea columella (Say, 1817), intermediate host of Fasciola hepatica (Linnaeus, 1758) in municipalities of the São Paulo State, Brazil. Brazilian Journal of Veterinary Research and Animal Science, vol. 35, no. 4, pp. 151-155. http://dx.doi.org/10.1590/S141395961998000400001

MEDEIROS, C., SCHOLTE, R.G.C., D’ÁVILA, S., CALDEIRA, R.L. and CARVALHO, O.S., 2014. Spatial Distribution of Lymnaeidae (Mollusca, Basommatophora), Intermediate Host of Fasciola hepatica (Linnaeus, 1758) (Trematoda, Digenea) in Brazil. Revista do Instituto de Medicina Tropical de Sao Paulo, vol. 56, no. 3, pp. 235-252. http://dx.doi.org/10.1590/S003646652014000300010. PMid:24879003.

MÜLLER, G., BERNE, M.E.A., RAFFI, L.L., JESUS, L.P., PAULSEN, R.M.M. and SINKOC, A.L., 1999. Influence of temperature on longevity of metacercariae of Fasciola hepatica. Revista Brasileira de Agrociência, vol. 5, no. 2, pp. 164-165.

OLLERENSHAW, C.B., 1971. Some observations on the epidemiology of Fascioliasis in relation to the timing of molluscicide applications in the control of the disease. The Veterinary Record, vol. 88, no. 6, pp. 152-164. http://dx.doi.org/10.1136/vr.88.6.152. PMid:5102169.

PARAENSE, W.L., 1975. Current status of the systematics of Brazilian snails. Arquivos do Museu Nacional do Rio de Janeiro, vol. 55, pp. 105-128.

PARAENSE, W.L., 1983. Lymnaea columella in Northern Brazil. Memorias do Instituto Oswaldo Cruz, vol. 78, no. 4, pp. 477-482. http://dx.doi.org/10.1590/S0074-02761983000400011.

PARAENSE, W.L., 1986. Physa marmorata Guilding, 1828 (Pulmonata: Physidae). Memorias do Instituto Oswaldo Cruz, vol. 91, no. 4, pp. 459-469. http://dx.doi.org/10.1590/S007402761986000400014 .

PREPELITCHI, L., PIETROKOVSKY, S., KLEIMAN, F., RUBEL, D., ISSIA, L., MORIENA, R., RACIOPPI, O., ÁLVAREZ, 
J. and WISNIVESKY-COLLI, C., 2011. Population structure and dynamics of Lymnaea columella (Say, 1817) (Gastropoda: Lymnaeidae) in wetlands of northeastern Argentina. Zoological Studies (Taipei, Taiwan), vol. 50, no. 2, pp. 164-176.

RUSSEL-HUNTER, W., 1961. Annual variations in growth and density in natural populations of freshwater snails in the West of Scotland. Proceedings of the Zoological Society of London, vol. 136, no. 2, pp. 219-253. http://dx.doi.org/10.1111/j.1469-7998.1961. tb06175.x.

SERRA-FREIRE, N.M., 1990. Fasciolosis in the Paraíba Valley. Agrotécnica Ciba-Geigy, vol. 14, no. 1, pp. 14-19.
SERRA-FREIRE, N.M., 1995. Fasciolosis hepatica. A Hora Veterinária, vol. 1, no. 1, pp. 13-18.

TOLEDO, J.V., MARTINS, L.D., KLIPPEL, V.H., PEZZOPANE, J.E.M., TOMAZ, M.A. and AMARAL, J.F.T., 2009. Agro-Climatic Zoning for The Cultivation Jatropha (Jatropha curcas L.) and Castor (Ricinus communis L.) in the State of the Espírito Santo. Agropecuária Científica no Semi-Árido, vol. 5, pp. 41-51.

TORGERSON, P. and CLAXTON, J., 1999. Epidemiology and control. In: J.P. DALTON, ed. Fasciolosis. London: CABI International, pp. 113-149. 